Jurnal Ilmu Keolahragaan Volume II Nomor 2 Oktober 2019

Novi Yanti

Tersedia di: http://jurnal.untan.ac.id/index.php/jilo

\title{
KONTRIBUSI KEKUATAN PERAS TANGAN TERHADAP \\ HASIL SERVIS ATAS PADA BOLA VOLI
}

\author{
NOVI YANTI \\ Prodi Pendidikan Jasmani FKIP Universitas Tanjungpura \\ Email: noviyanti@fkip.untan.ac.id
}

\begin{abstract}
ABSTRAK
Penelitian ini bertujuan untuk mengetahui kontribusi kekuatan otot peras tangan terhadap kemampuan servis atas mahasiswa putra pembinaan prestasi bola voli FKIP UNTAN. Partisipan dalam penelitian ini adalah seluruh mahasiswa putra yang mengikuti pembinaan prestasi bola voli FKIP UNTAN yang latihannya berpusat di Kampus 3 Jurusan Olahraga FKIP UNTAN dengan jumlah partisipan sebanyak 20 Orang. Jenis penelitian ini adalah penelitian kuantitatif dengan analisis korelasional. Instrumen yang dipergunakan dalam penelitian ini hand grip strength dynamometer dan servis atas bola voli. Dalam penelitian ini hasil pengujian hipotesis tidak terdapat hubungan antara kekuatan otot peras tangan, terhadap keterampilan servis atas. Hal ini menunjukkan bahwa kekuatan peras tangan kurang memberikan kontribusi terhadap keterampilan servis atas.
\end{abstract}

Kata Kunci: Peras Tangan, Servis Atas 


\section{Jurnal Ilmu Keolahragaan Volume II Nomor 2 Oktober 2019 Novi Yanti \\ Tersedia di: http://jurnal.untan.ac.id/index.php/jilo}

\section{PENDAHULUAN}

Olahraga bola voli di Indonesia merupakan salah satu olahraga yang sangat popular dan di gemari oleh masyarakat baik dikota maupun di desa, karena permainan bola voli dapat dimainkan dari berbagai kalangan, baik anak-anak, remaja dan orang dewasa, baik pria maupun wanita (Hakim, 2012, P.38). Olah raga bola voli juga sudah masuk dalam lingkup pendidikan, dimana sudah masuk dalam kurikulum sekolah. Antusias masyarakat yang tinggi, sehingga banyak sekali diadakannya event-event atau pertandingan-pertandingan bola voli baik dalam acara-acara kemerdekaan, kejuaraan antar sekolah, antar perguruan tinggi, antar klub-klub, antar lembaga, acara program tahunan pendidikan, dan agenda tetap kejuaraan nasioanl, bahkan kejuaraan pada tinggkat internasional lainnya.

Upaya menghasilkan pemainpemain atau atlet bola voli yang baik dan berprestasi banyak aspek yang perlu diperhatikan, salah satunya penguasaan tehnik dasar olaraga bola voli tersebut, dimana penguasaan teknik dasar merupakan suatu prasyarat yang harus dimiliki oleh setiap pemain,atau atlet agar permainan dapat dilakukan dengan baik. Kemampuan penguasaan teknik dasar permainan Bola Voli menentukan sampai dimana seorang pemain dapat meningkatkan mutu permainannya. Salah satunya servis yang kali ini akan dibahas oleh penulis.

Servis dalam permainan bola voli merupakan tanda awal dimulainya permainan (Hidayat \& Wardaya, 2015. P.130). Servis merupakan hal yang sangat penting dalam permainan Bola Voli. Selain ditunjang penguasaan tehnik dasar lainnya yang baik pemain juga harus mahir melakukan servis terhadap bola, sebab servis merupakan salah satu keterampilan yang sangat menunjang dalam permainan Bola Voli, terutama saat mengawali suatu permainan bola voli dan perolehan poin serta penentu kemenangan. Tidak hanya itu saja saat ini servis juga dapat dijadikan suatu senjata serangan pertama kali bagi tim yang mendapatkan kesempatan servis (Hakim, 2012, P.41). Terdapat dua jenis servis, yakni servis bawah dan servis atas. Dalam prakteknya penggunaan servis atas yang paling sering atau dominan dipergunakan dalam pertandingan, sebab servis atas cukup efektip, karena arah lajunya bola lebih tajam, mematikan dan dapat mengarahkan sasaran yang akan dituju, sehingga dapat menambah perolehan angka/poin.

Servis atas pelaksanaannya membutuhkan keterampilan untuk pengaturan atau pengolahan bola, baik arah atau jutuan serta sasaran, laju pendeknya pergerakan laju bola, ini diperlukan tenaga gerak atau kekuatan kearah bola dengan cara dipukul melalui media atau perantara tangan, terutama yang dominan pada bagian jari-jari tangan.

Penunjang dalam hasil keterampilan servis atas yang efektif dan akurat dibutuhkan beberapa faktor pendukung didalamnya selain kodisi fisik yang bagus atau prima salah satunya yang dominan yaitu kekuatan. Kekuatan merupakan salah satu komponen dari kondisi fisik yang sangat mendukung dalam prestasi olahraga. Dengan memiliki struktur otot yang kuat dengan cera otomatis dapat menghasilkan kekuatan yg lebih efisien (Putri \& Cahyani, 2019, P.24). Penelitian ini yang dimaksud otomatis pada bagian tangan yang merupakan anggota tubuh yang langsung terhubung dengan pergerakan servis atas terutama bagian jari-jari tangan yang secara kangsung bersentuhan dengan bola.

Jari-jari tangan dalam hal ini disebut dengan kekuatan peras tangan, dimana peras tangan merupakan salah satu komponen kondisi fisik yang masuk dalam 


\section{Jurnal Ilmu Keolahragaan Volume II Nomor 2 Oktober 2019 Novi Yanti Tersedia di: http://jurnal.untan.ac.id/index.php/jilo}

komponen kekuatan, Hal ini mendapat perhatian khusus apakah benar dengan kemampuan kekuatan peras otot tangan yang baik dapat menghasilkan servis atas yang baik pula. Menyangkut hal ini untuk melakukan gerak peras tangan dengan sekuat tenaga yang bisa diukur dengan menggunakan Grip strength dynamometer (BARKAH CHOLISTIAN, 2013, P.24)

Dengan itu dapat disimpulkan bahwa servis sangat mempengaruhi dalam jalannya pertandingan, karena dengan penguasaan teknik servis yang baik terutama servis atas didukung dengan kemampuan kekuatan yang maksimal dapat menghasilkan arah bola sesuai dengan sasaran yang dituju dan dapat mematikan lawan dengan mengarahkan bola pada tempat-tempat yang susah dijangkau.

Berdasarkan penjelasan di atas, dalam penelitian ini diteliti kontribusi kekuatan otot peras tangan terhadap hasil servis atas pada olahraga bola voli, mahasiswa putra FKIP UNTAN pembinaa prestasi bola voli.

\section{METODE}

Penelitian ini menggunakan jenis penelitian deskriptif kuantitatif, dengan menggunakan analisis korelasional product moment. Pelaksanaan penelitian dilakukan di lapangan bola voli kampus 3 Jurusan Ilmu Keolahragaan FKIP UNTAN. Kekuatan Otot peras tangan sebagai variabel bebas dan hasil servis atas sebagai variabel terikat. Partisipan dalam penelitian ini adalah seluruh mahasiswa putra yang mengikuti pembinaan prestasi bola voli FKIP UNTAN yang berlokasi di kampus 3 Jurusan Ilmu Keolahragaan sebanyak 20 mahasiswa putra. Instrumen yang dipergunakan dalam pengambilan data adalah Hand grip Dynamometer dan tes kemampuan service.

\section{HASIL}

Data penelitian diperoleh dari 20 mahasiswa dengan mengukur variabel kekuatan peras tangan (X) dan keterampilan servis atas bola voli (Y). secara sistematis penyajian data penelitian kekuatan peras tangan dan keterampilan servis atas, dimana data tersebut disajikan dan disusun berdasarkan skor yang tertinggi, skor yang terendah, rerata $\mathrm{X}$ (mean), standar deviasi, modus, dan median. Selanjutnya disajikan dalam bentuk tabel distribusi frekuensi sebagai berikut:

Tabel 1. Deskripsi Hasil Penelitian Data Variabel kekuatan peras tangan (X) dan keterampilan servis atas bola voli $(\mathbf{Y})$

\begin{tabular}{lrrr}
\hline & & & \multicolumn{1}{r}{ X } \\
\hline \multirow{2}{*}{ N } & Valid & 20 & 20 \\
\cline { 2 - 4 } & Missing & 0 & 0 \\
\hline Mean & 32.8500 & 13.8000 \\
\hline Median & 27.7500 & 14.5000 \\
\hline Mode & $15.50^{\mathrm{a}}$ & 15.00 \\
\hline Std. Deviation & 13.89633 & 4.64078 \\
\hline Minimum & 15.50 & 5.00 \\
\hline Maximum & 57.50 & 22.00 \\
\hline a. Multiple modes exist. The smallest value is shown & \\
\hline
\end{tabular}




\section{Jurnal Ilmu Keolahragaan Volume II Nomor 2 Oktober 2019 \\ Novi Yanti \\ Tersedia di: http://jurnal.untan.ac.id/index.php/jilo}

Berdasarkan pengolahan data dari hasil tes kekuatan otot peras tangan (X) diperoleh skor terendah 15.50, skor tertinggi 57.50, skor rata-rata (mean) sebesar 32.8500, standar deviasi (Sd) sebesar 13.89633, Modus sebesar 15.50 dan Median sebesar 27.7500. Hasil dari tes kemampuan service adalah sebagai berikut; diperoleh skor terendah 5.00, skor tertinggi 22.00 , skor rata-rata (mean) sebesar
13.8000, standar deviasi (Sd) sebesar 4.64078, modus sebesar 15.00 dan median sebesar 14.5000 .

Hasil perhitungan data di atas dapat dilihat dalam bentuk histogram seperti pada gambar 1,

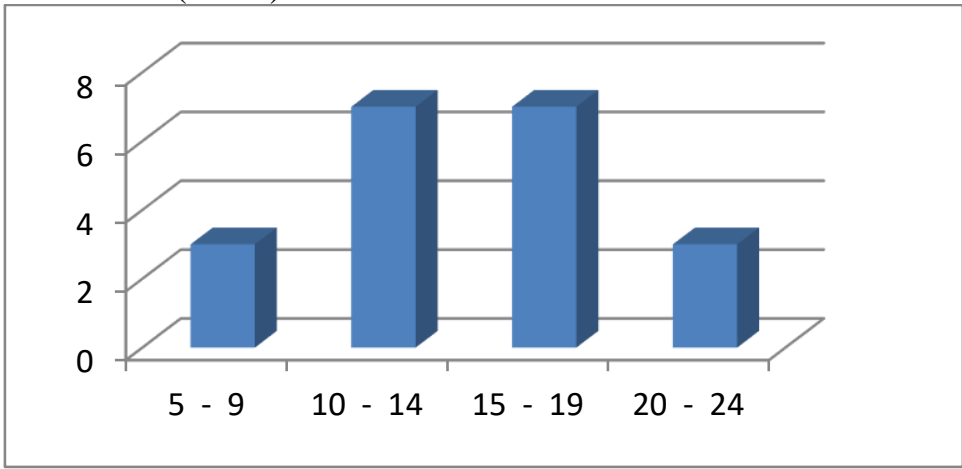

Gambar 1. Histogram hasil service

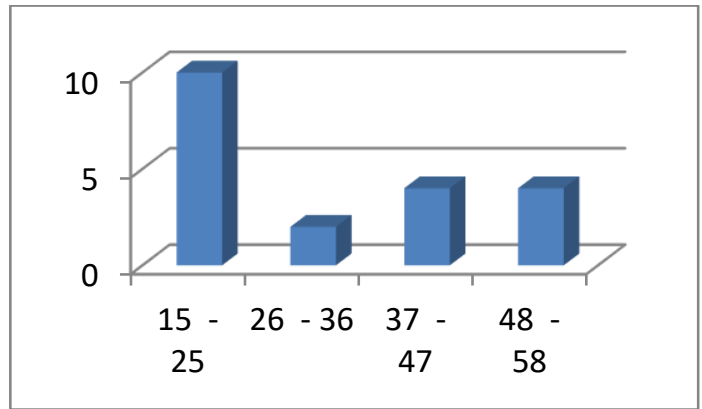

Gambar 2. Histogram Kekuatan Peras Tangan

Selanjutnya untuk mengetahui keeratan hubungan antara kekuatan peras tangan terhadap hasil servis atas, maka dilakukan perhitungan korelasi sederhana dan uji signifikansi. Berdasarkan perhitungan maka diperoleh korelasi sederhana $=0.109$. Selanjutnya setelah diketahui koefisien korelasi antara X dan Y kurang signifikan, dihitung nilai signigikansi hitung signifikansi adalah 0.647 . Hasil ini menunjukkan bahwa kekuatan remas tangan kurang dapat dijadikan variabel untuk meningkatan kemampuan service atas. 


\section{Jurnal Ilmu Keolahragaan Volume II Nomor 2 Oktober 2019 Novi Yanti Tersedia di: http://jurnal.untan.ac.id/index.php/jilo}

Tabel 2. Hasil analisis korelasi variabel X dan $Y$.

\begin{tabular}{llrr}
\hline \multicolumn{4}{c}{ Correlations } \\
\hline & $\mathrm{x}$ & $\mathrm{y}$ \\
\hline $\mathrm{x}$ & 1 & .109 \\
\cline { 2 - 4 } & Pearson Correlation & & .647 \\
\cline { 2 - 4 } Sig. (2-tailed) & 20 & 20 \\
\cline { 2 - 4 } $\mathrm{N}$ & .109 & 1 \\
\cline { 2 - 4 } & Pearson Correlation & .647 & \\
\cline { 2 - 4 } & Sig. (2-tailed) & 20 & 20 \\
\cline { 2 - 4 } & & &
\end{tabular}

\section{PEMBAHASAN}

Berdasarkan hasil analisis data dan uji hipotesis dapat disimpulkan bahwa kemampuan peras tangan kurang dapat dijadikan indicator dalam kemampuan service atas. Hal ini dapat dilihat berdasarkan nilai korelasi antara kekuatan peras tangan dan hasil prestasi service atas. Berdasarkan pada hasil analisis tersebut dapat dinyatakan bahwa kekuatan peras hubungannya dengan kemampuan service khususnya service atas dalam penelitian ini peranannya sangat kecil. Hal ini tidak dapat dipahami jika kekuatan peras semakin besar maka hasil service atas akan semakin baik. Bebarapa hasil penelitian terdahuli tentang service di volley ini telah dilakukan. Beberapa diantaranya yaitu menurut Mirjana Milic et. all (2013) terdapat 4 faktor yang dapat dipakai sebagai indicator kualitas pemain volley pada atlet putri di Kroasia, yaitu power dan kelincahan (tungkai), presisi, power dan kelenturan (lengan), keseimbangan. Keseimbangan dan presisi berpengaruh signigikan terhadap efisiensi pemahaman situasi sedangkan factor power tungkai dan kelincahan meruakan factor yang dominan memiliki kontribusi yang sangat besar. Yüksel et. all (2018) penelitian ini menyatakan bahwa aktivitas latihan volley akan mempengaruhi antopometri.
Muin (2017) menyatakan bahwa Kontribusi kekuatan lengan 5,3\%, koordinasi mata tangan $40,7 \%$ dan panjang lengan $1.9 \%$ dan gabungan dari ketiga hal tersebut adalah 47,9\%. Berdasarkan pada hasil penelitian Muin ini ternyata kontribusi kekuatan lengan hasilnya kecil. Hal ini sama dengan hasil penelitian yang peneliti lakukan, dimana kekuatan peras tangan memiliki paranan yang kecil terhadap hasil service, lebih besar adalah koordinasi mata tangan. Maria Lestari dkk (2016) ternyata koordinasi mata tangan menyumbang $25 \%$ dan power lengan $21 \%$. Berdasarkan pada penelitian ini juga memberikan gambaran bahwa yang lebih utama adalah koordinasi dan power pada lengan, bukan kekuatan peras tangan.

Penelitian yang dilakukan oleh M. Soyal et. all (2019) kaitan antara range of motion pada sendi bahu terhadap pukulan dalam tenis, hasilnya kedua variabel ini berkorelasi 0.5 pada kemampuan adduksi bahu, kemampuan tangan melakukan ekstensi 0,67, kemampua tangan melakukan fleksi 0.63, kemampuan untuk bahu untuk melakukan raihan ke atas 0.819 , dan kesimpulannya menyatakan bahwa kemampuan range of motion sendi bahu memiliki hubungan. Penelitian ini memberikan gambaran bahwa yang terpenting adalah kemampuan sendi untuk melakukan gerakan dalam jangkuan gerak. 


\section{Jurnal Ilmu Keolahragaan Volume II Nomor 2 Oktober 2019 Novi Yanti \\ Tersedia di: http://jurnal.untan.ac.id/index.php/jilo}

Berdasarkan penelitian ini dapat dibandingkan bahwa semakin range of motionnya baik maka kecepatan service dalam tenis akan semakin tinggi. Dalam penelitian yang dilaksanakan dalam penelitian ini hanya melihat kekuatan remas secara statis, sehingga hasilnya berkorelasi kecil. Dalam penelitian-penelitian terdahulu korelasi antara variabel cukup besar, hal ini disebabkan adanya kesamaan gerakan antara variabel yang diteliti dengan variabel yang manjadi pasangan.

\section{KESIMPULAN}

Hasil pengujian hipotesis terdapat hubungan yang kecil antara kekuatan otot peras tangan $(\mathrm{X})$, dengan hasil servis atas pada olahraga bola voli (Y). Hal ini terbukti dari hasil perolehan koefisien korelasi $\left(\mathrm{ry}_{1}\right)$ sebesar 0.109. Kekuatan peras tangan (X) memberikan sumbangan yang kecil terhadap keterampilan servis atas pada olahrahraga bola voli (Y). Data tersebut diperoleh dari hasil penghitungan koefisien korelasi. Ini menunjukkan bahwa kekuatan peras tangan kurang memberikan sumbangan terhadap keterampilan servis atas pada olahraga bola voli.

Dari hasil tersebut dapat disimpulkan semakin baik kekuatan peras tangan, maka belum tentu memberikan pengaruh terhadap kemampuan service. Maka dapaat disimpulkan bahwa kemampuan peras tangan kurang berkorelasi dengan kemampuan service atas.

\section{DAFTAR PUSTAKA}

Anne Shumway-Cook \& Marjorie H.

Woollacott, (2001) "Motor Control"

Theory and Practical Applications.

Second Edition. Walnut Street

Philadelphia Pennsylvania USA.

Arikunto, Suharsimi, Prosedur Penelitian

Statu Pendekatan Praktik Edisi Revisi
VI. Jakarta : PT RINEKA CIPTA, 2006

BARKAH CHOLISTIAN, T. I. O. (2013). Hubungan Antara Kekuatan Otot Lengan Dan Kekuatan Otot Peras Tangan Dengan Kemampuan Forehand Drive Pada Olahraga Tenis Lapangan. Jurnal Kesehatan Olahraga, 1(3).

Hakim, H. (2012). Kontribusi daya ledak lengan dan kelentukan togok ke belakang terhadap keterampilan servis atas bolavoli pada siswa sma negeri 2 bantaeng. COMPETITOR: Jurnal Pendidikan Kepelatihan Olahraga, 4(2).

Hidayat, A. S. N., \& Wardaya, H. D. (2015). Peningkatan Pembelajaran Servis Atas Bolavoli Melalui Metode Team Games Tournament Kelas Xi Mia 5 Sman 1 Sleman. Jurnal Pendidikan Jasmani Indonesia, 11(2).

Putri, W. S. K., \& Cahyani, O. D. (2019). Tingkat konsentrasi, kekuatan otot peras tangan, dan kekuatan otot bahu terhadap hasil tembakan. Altius: Jurnal Ilmu Olahraga Dan Kesehatan, 8(1).

Maria Lestari, Saripin Saripin, Ardiah Juita (2016) Kontribusi Daya Ledak Otot Lengan dan Koordinasi Matatangan terhadap Ketepatan Servis Atas Pemain Bola Voli Sman 1 Teluk Nisap Kecamatan Kubu Babussalam.

https://www.neliti.com/publications/ 202682/kontribusi-daya-ledak-ototlengan-dan-koordinasi-mata-tanganterhadap-ketepatan

Mirjana Milic, Zoran Grgantov, Ratko Katic (2013) Impact of Biomotor Dimensions on Player Quality in Young Female Volleybal Players. https://hrcak.srce.hr/index.php?id_cl anak_jezik $=146514 \&$ show=clanak 


\section{Jurnal Ilmu Keolahragaan Volume II Nomor 2 Oktober 2019 Novi Yanti Tersedia di: http://jurnal.untan.ac.id/index.php/jilo}

M. Soyal, M. Kaya, N.M. Çelik (2019)

Examining the relationship between joint range of motion and serve speed and hit.

https://sportedu.org.ua/index.php/PE S/article/view/837

MUIN (2017) Kontribusi kekuatan otot lengan, panjang lengan dan koordinasi mata tangan terhadap ketepatan service atas bolavoli (studi pada klub bolavoli bayonet kab.

Sampang.

https://jurnalmahasiswa.unesa.ac.id/i ndex.php/jurnal-prestasi-

olahraga/article/view/19644

Munafisah, Bermain Bola Voli, CV.

Aneka Ilmu, Semarang; 2008

Nurhasan, Tes dan Pengukuran. Surabaya: Perpustakaan FIK Universitas Negeri Surabaya, 2003

Nurhasan, Tes dan Pengukuran Pengantar Kegunaan Tes dan Pengukuran Kriteria Tes Di perbanyak oleh perpustakaan FIK Universitas Negeri Surabaya, 2003.

Santoso, Gempur, Metodologi Penelitian Kuantitatif dan Kualitatif. Jakarta: Prestasi Pustaka Publisher, 2005 Sport Equipment Training : PT. Tripatria Andalan Medika

Sujana, Teknik Analisis Regresi dan Korelasi , Bandung: Tarsito, 1992

Viera. L Barbara dan Fergusson. Bonne Jill, Bola Voli Tingkat Pemula, Jakarta: PT. Raja Gravindo Persada, 2004

Yüksel, Mehmet Fatih; Sevindi, Tarik (2018). Physical Fitness Profiles of Sitting Volleyball Players of the Turkish National Team. https://eric.ed.gov/?id=EJ1171312 